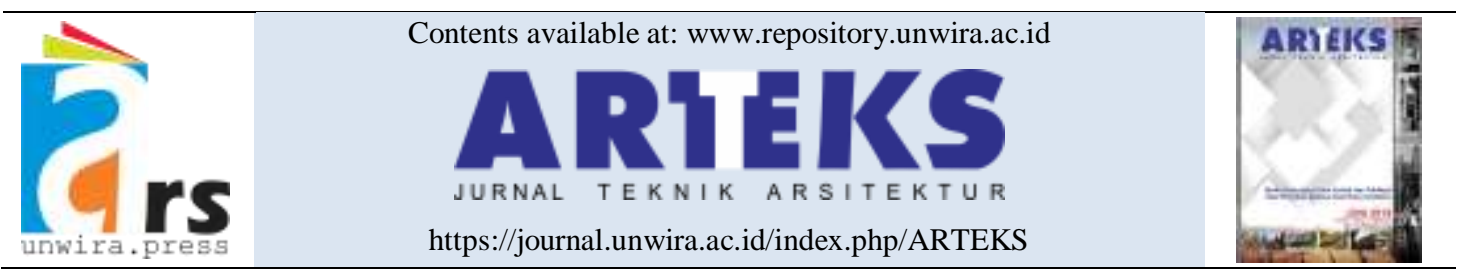

Research paper

doi: https://doi.org/10.30822/arteks.v3i2.63

\title{
The interiority of proximity between nature and arhitecture in contemporary and tropically context with cases studies
}

\section{Budi Pradono}

Budipradono architects $a+u$

Jl. Walet 6 blok I. 2 no 11, Sector 2, Bintaro Jaya, Jakarta Selatan 12330, Indonesia

\begin{tabular}{|c|c|}
\hline ARTICLE INFO & ABSTRACT \\
\hline $\begin{array}{l}\text { Article history: } \\
\text { Received February 14, } 2019 \\
\text { Received in revised form Feb. 25, } 2019 \\
\text { Accepted May 26, } 2019 \\
\text { Available online June 01, } 2019\end{array}$ & $\begin{array}{l}\text { The interiority of buildings in tropical countries requires specific } \\
\text { characteristics unlike those in countries with four distinct seasons. } \\
\text { Buildings in non-tropical climates must protect their inhabitants } \\
\text { from extreme weather, meaning that the architecture's connection } \\
\text { with nature is necessarily limited by a boundary which can } \\
\text { withstand extreme climatic differences. In tropical countries, on the }\end{array}$ \\
\hline $\begin{array}{l}\text { Keywords: } \\
\text { Tropical } \\
\text { Contemporary } \\
\text { Relationship between nature and } \\
\text { architecture }\end{array}$ & $\begin{array}{l}\text { other hand, the temperature does not fluctuate much throughout the } \\
\text { year, so the temperature difference between seasons is not extreme. } \\
\text { This characteristic is reflected in traditional Nusantara } \\
\text { architecture, which incorporates a breathable wall so that free } \\
\text { winds come in, reducing heat. The roof is tilted or saddled-shaped } \\
\text { to keep rain water away from the building. The architecture uses } \\
\text { organic materials and includes terraces for dialogue with nature. } \\
\text { Modern Indonesian architecture, however, particularly in large } \\
\text { cities, is mostly closed off, severely limiting the interaction with } \\
\text { nature. Since the advent of air conditioning (AC) technology during } \\
\text { the } 1980 \text { 's, architecture has changed to seal the boundaries of the } \\
\text { building. Advances in information technology such as Internet and } \\
\text { smartphones have made for further changes to architecture in the } \\
\text { area; some functional spaces are being discarded, while others are } \\
\text { expanded. The relationship between architecture and nature is now } \\
\text { constrained by impenetrable materials such as brick, concrete and } \\
\text { glass, as opposed to the more traditional, permeable boundary. In } \\
\text { contrast to this trend, modern Indonesian society is tempted to form } \\
\text { a closer relationship with nature. This paper examines how a } \\
\text { relationship between nature and the interior of buildings may be }\end{array}$ \\
\hline $\begin{array}{l}\text { Corresponding author: Budi Pradono } \\
\text { Budipradono architects a+u, Indonesia } \\
\text { Email: pradono.budi@gmail.com }\end{array}$ & $\begin{array}{l}\text { accommodated again, presenting some existing projects by several, } \\
\text { architects from Europe and Asian countries-including the authors } \\
\text { own work-as case studies. }\end{array}$ \\
\hline
\end{tabular}

\section{Introduction}

Interiority may be defined not only with dimension, colour and the materials that form the basis of interior space (P. S. Perolini 2011), but also as an abstract presence associated with the interior space-not the interior itself, but an abstract quality bringing various possibilities and interpretations of interior space. Interiority is not static but mobile, a fusion of physical space, intangible concepts and abstractness. In 1967, Michel Faucault defined 'heterotopias', or places that are neither here nor there, as real spaces that stand outside of the accepted space. Faucault describes heterotopias as spaces which are constructed by the mind but are equally likely to have a physical presence and action (P. Perolini 2013). 
Another theory, put forward by Henry Lefebvre in his paper, The Production of Space, defines space as a social product. Lefebvre explains the fundamental difference between architectural space and the space of architects as follows: while architectural space produces social space through experiences, the space of architects is space manipulated and affected by the architects as part of their professional practice. He claims that a space that the architect of an event is not the same as the experience of everyday life ( $\mathrm{P}$. Perolini 2013).

Architects and designers must create meaningful experiences for occupants of the spaces they design. It is important to realise that interiority and exteriority are interwoven within architectural constraints but are not defined by the boundaries of buildings. Interiority is abstract and fluid; the concept of interiority relies upon cultural, social, technological and physical developments in society.

The main purpose of this paper is to discuss the current phenomenon of proximity between architecture and nature, which may affect the quality of abstract space or interiority. The quality of the space quite specific where the architect's or designer's experience comes into play, since the advancement of technology permits the integration nature into the interior space. In contrast to previous research, where tropical architecture is discussed in terms of highly technical areas addressing only humidity and heat. Very little research addresses the abstract quality of space attributable to the incorporation of nature and architecture. This paper focuses on the relationship between architecture and nature, the history of tropical architecture as associated with post-colonial discourse, green architecture, Nusantara architecture, bhiophilic architecture and its relation to technological advances in communication, contemporary tropical architecture as related to proximity with nature and the quality of imaginary space irrespective of climate.

\section{Findings and discussion}

\section{The relationship between architecture and nature}

Historically, architecture was governed by the forces of nature, and humans relied more upon their instinct to survive. The relationship between architecture and nature has changed radically over time, especially with the arrival of the industrial and technological revolutions. After World War II, the demand for construction boomed. However, heavy construction's impact on the environment has become evident, and people have come to pay closer attention to ecology in recent years. This paper discusses many architectural trends arising from an understanding of the importance of a good relationship with nature and current nostalgia for a time when man and nature were closer, as closeness with nature is a need. It focuses on the phenomenon of reestablishing a relationship between architecture and nature in tropical climates.

Mankind first began to manipulate nature as nomadic hunters. This eventually led to the birth of the permanent settlement and the development of architecture (Crowe 1995). The permanent settlement gave humans the ability to control the environment by adjusting materials in nature to address their needs, in effect creating new nature in the form of houses. Traditional societies tried to reflect the macrocosm in the microcosm of the building, with the roof as a metaphor of the sky, the fireplace representing the sun, the walls serving as the borders of the cosmos and the floor acting as the manifestation of the Earth. This represents a strong relationship between nature and humankind. Local materials were historically chosen due to their proximity and suitability to the local weather. For example, walls made of clay transmit heat slowly, lowering the interior temperature during the day and keeping it from getting too low at night (Rinaldi 2009). Clay walls may be found not only in North Africa and Morocco, but also in several areas of Indonesia, including the mountainous area of Ubud, Bali. Tropical regions, with their high temperatures and day-and-night humidity, generally use wood and bamboo in their architecture. This reflects a primitive principal whereby architecture is seen as part of nature and has the benefit of using less manmade energy (Crowe 1995). 

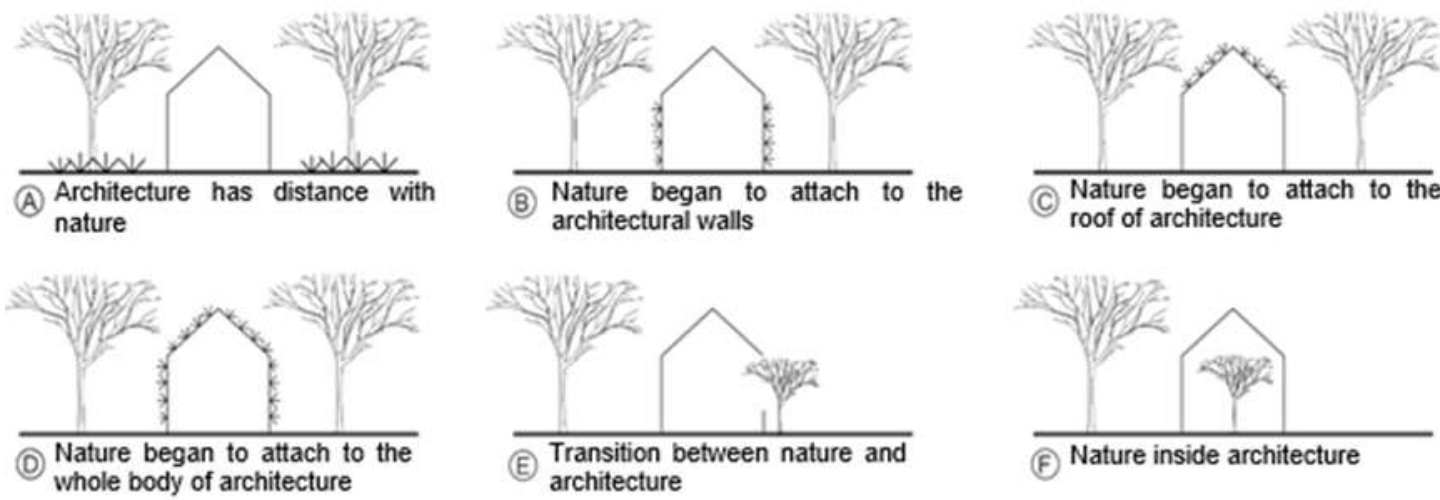

Figure 1. The different relation between architecture and nature

\section{Contemporary tropical architecture}

Tropical architecture lies beyond its climatic and regional concerns. This confronts the spread of a homogenous globalism which can also be called international style. Tropical architecture is always associated with a locally and environmentally sensitive approach.

Countries in the tropical belt have seen before growth in the last 70 years and are poised to escalate in terms of economic, technological and material development. Briefly, modern tropical architecture has been adapted from modern trends in design and construction to climate, where it is necessary to note the changes in the lifestyle that the tropical climate affords. What appears often is the exploration of open and semi-open spaces, balconies, verandah, and open plan.

The challenge to define a modern idiom for tropical architecture is not just a climatic issue but also related to the problem of adapting to the modern lifestyle, of transformation of local cultures to the modern city.

The research on tropical architecture is based on the movement of modernism in Europe and the US. The modern architecture movement was led by several master architects such as Le Corbusier, Oscar Niemeyer and Alvar Aalto who believed that Modernism in architecture ought not to be transplanted globally without some recognition of its context where emphasized the importance of understanding the region, climate and social context. At the moment there is a transplanted from temperate countries, particularly the US - in justification by the name of International Style.

This situation was criticized by many architectural schools and environmentalist writings such as Aladar Olgyay (1963) and Victor Olgyay (1952), Maxwell Fry (1956) and Jane
Drew (1964) as well as by modernist architects who showed with such works Paul Rudolf and Richard Neutra (US), Frederich Silaban, YB Mangunwijaya, and Han Awal (Indonesia).

In the current era where the advancement of innovation and digital technology has changed the social order in the contemporary architectural community is defined as the latest architecture that accommodates the needs of the current community lifestyle. So, the contemporary tropical architecture shows the geographical location of the tropics therefore some of the things below will explain more detail about the Nusantara architecture, Dutch colonial architecture in Jakarta, green architecture, and the influence of smartphone technology that changed the pattern of tropical space in the cities in Indonesia.

\section{Nusantara architecture and its relationship with nature}

Indonesia comprising thousands of islands, has many vernacular architectures on each of these islands. "Nusantara" is an Indonesian word for the Indonesian archipelago, coming from "Nusa" and "Antara" and meaning "a unity between islands and its seas" (Prijotomo 2008). Nusantara architecture is non-separated from nature; therefore, its materials come from nature, namely organic materials such as tree bark, wood, roots and leaves. The material adjusted based on natural condition. For example, rumah panggung or house on stilts is commonly in the region. Similarly, in Korowai, Papua, the tree house is common. This architecture is merged with nature, with breathable walls usually made of woven bamboo or from the arrangement of bebak (palm tree leaves). The traditional societies of these 
regions hold ceremonies when they cut the trees or harvest other natural materials for use as building materials. The ceremony is a symbol that the local people really appreciate God's creation such as trees so that cutting down trees is not as an economic commodity such as modern society but for the needs of the community creating Nusantara architecture to shelter.

This relationship between architecture and nature is different from that of the architecture in four-season countries. Extreme weather difference in non-tropical climates mean that their architecture tends to have rigid boundaries with nature; the architecture functions like a fortress, protecting the people inside from the cold or the heat.

\section{The garden city of menteng}

In 1909, Dutch East Indies architects tried to implement the garden city concept in Menteng, Jakarta, in early 20th-century Batavia. Garden City was a middle-class, residential area in Batavia. This urban planning movement attempted to transform Indonesia's traditional architecture into a more modern form using materials used in the Netherlands, such as brick. Garden City houses were surrounded by large gardens and tall trees. To address the heat, the houses were built with high ceilings and spacious terraces. The architecture incorporated nature as a cosmetic complement; residents could sit on the terrace and enjoy the nature around it. It also benefited from nature in a practical function, as most of the houses had fruit trees to provide food. Many of these buildings incorporated a terrace, as well as large gardens in front of and behind the building, as media to connect with nature. Others, called courtyard houses, incorporated a garden in the middle of the building, which served to cool the house by creating air flow into the building. The use of plants in this architectural style may be categorized as fence, marker, canopy and decorative element. During this period, the relationship between architecture and nature was only partly for the beautification of the house.

\section{0s economy boom and the introduction of modern architecture}

An economy boom in 1970s Indonesia brought some first-generation, newly-graduated architects from the Netherlands and Germany, including Han Awal and Suwondo, who attempted to introduce tropical architecture in Indonesia. Han Awal designed houses with atriums or backyards and more spacious bathrooms incorporating plant life. In this era, as the state enjoyed the financial boon of increased exports of crude oil and other mining materials, development in major cities in Indonesia increased. Deforestation was unrestrained, even in areas such as Borneo Island, known for its forest land, and the wood was exported for profit. Nature was viewed as a commodity and an unimportant material, as it was only used as a decorative addition to architecture.

This development took place in every corner of cities in Indonesia, despite the small number of young architects responsible for it. This era of exploitation and usage of nature diminished the relationship between architecture and nature.

\section{Nature and interior architecture}

There are several reasons to incorporate nature in interior architecture. Nature may be part of home decoration, such as potted plants. Plant life may serve to cool the house, which is achieved by creating a canopy frame for plants, so they can grow in above of the terrace, and the inside of the building will become cooler. Plants may also be placed between rooms such as patio or atrium to serve as connectors between different rooms. Plants placed inside the house may indicate that the owner has a psychological desire for closeness to nature, sometimes to the point - particularly in the case of elderly homeowners-where the plants serve as companionship, sometimes even giving the owners a reason to live. Building interiors which incorporate nature have a specific character and generally incorporate sunlight, as well, via architectural features such as atriums. Otherwise, such buildings must use artificial lighting as a replacement for sunlight.

Examining R-House, as a case study, we see a house with a cohabitation theme. This house has a special relationship with nature, both indoors and outdoors. As the owner of the house has a hobby related to water, water has been used as an element of design, flowing in from the outside and filling almost every corner of the room it flows into. Plants on the flat roof penetrate into the house, becoming a non-separated part of the interior of the house. 

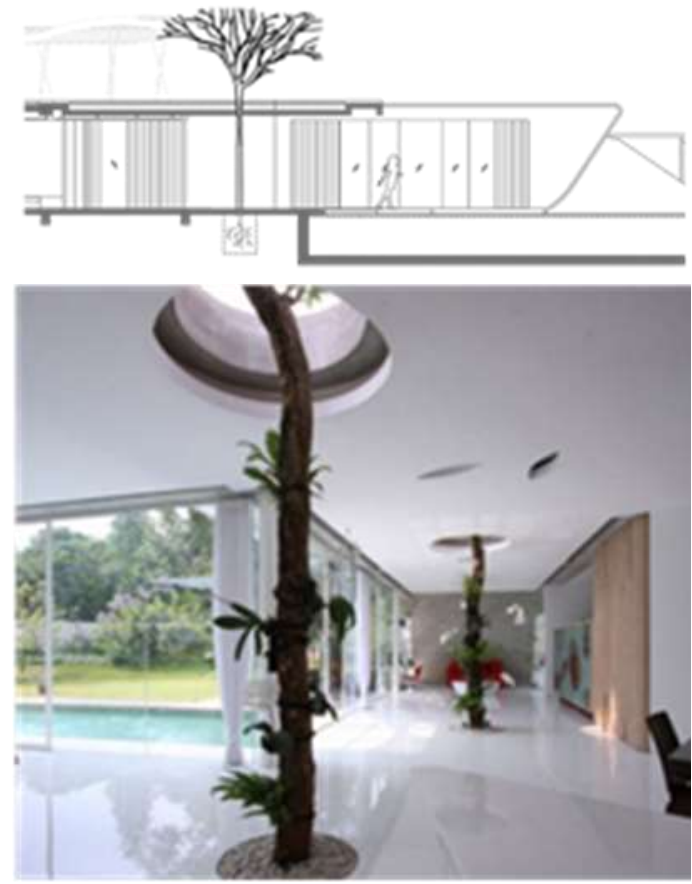

Figure 2. R-House section and interior, by BPA Architects. Reprinted from Budi Pradono's Naturally cooled R-House brings nature indoors, by M. Andrew, 21, retrieved October 30, 2017

The second case study is A-House in Bintaro, located in the southern part of Jakarta. Here, a tree was planted inside the house to create a dialogue between architecture and nature, as well as with the inhabitants of the house (Pradono 2014).

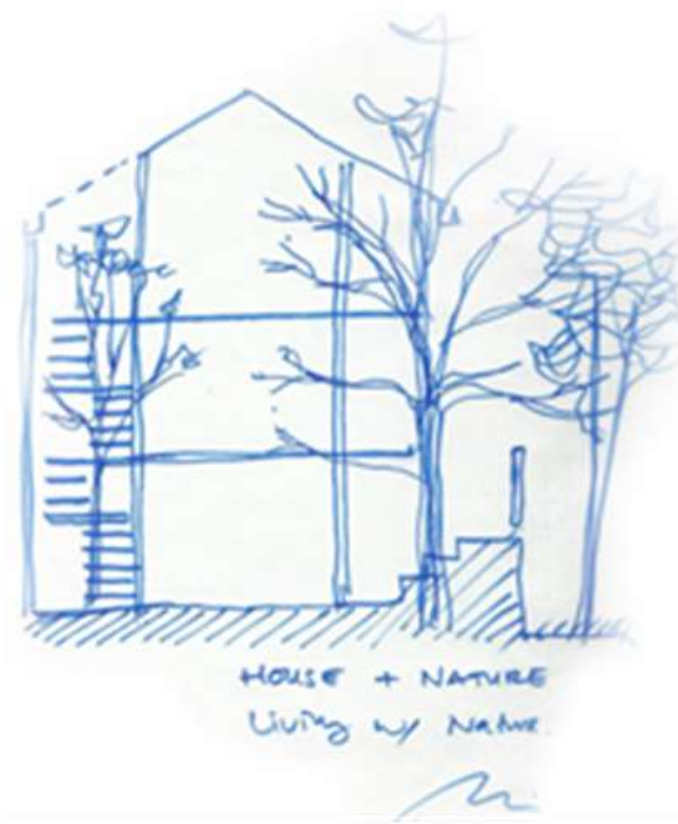

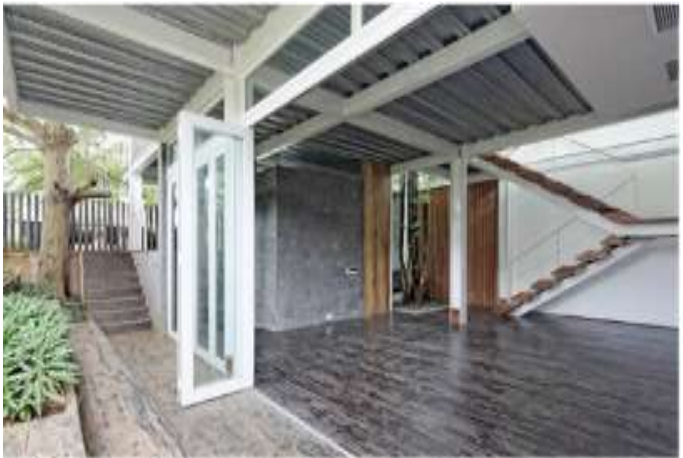

Figure 3. A-House, by BPA Architects, 2014

The next case study is the Rumah Miring, or Slanted House. The entire Slanted House building was lifted on pilotis and the pool was incorporated pool into the building. Many plants were sown around the building, as well as on the second-floor terrace so that the owner of this house may commune with nature when on the first floor. The bathroom was made spacious and wired for various digital activities (Pradono 2014).

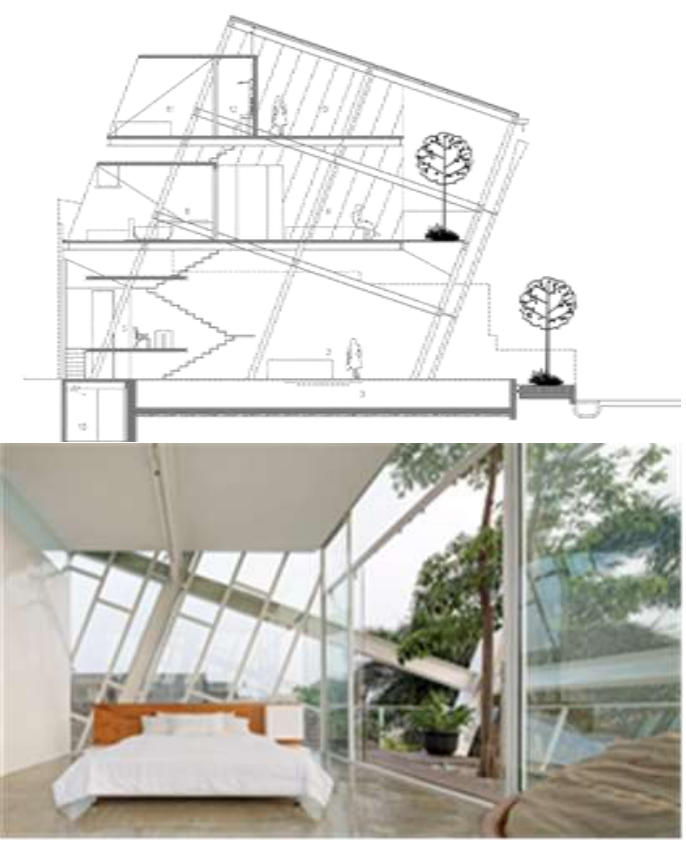

Figure 4. Slanted house section and interior, by BPA Architect, 2014

\section{Redefining of the relationship}

The relationship between nature and architecture must be redefined, given the current prevalence of nature degradation and technology development. The demand is high for environmentally responsible architecture, 
supporting sustainability. In Europe, the green architecture movement was triggered by the human desire to be close to nature and involves incorporating plants in buildings. In Indonesia, nature becomes a non-separated part of architecture. However, plants also serve as decoration for architecture. For example, the Vertical Forest Apartment by architect and theoretician Stefano Boeri features a façade covered entirely with plants. This successful Milan project is known as an example of architecture which lives together with nature. Boeri received several similar projects in Lausanne, Switzerland; Guizhou and Liuzhou in China; Utrecht; Paris; Tirana and Shanghai. His idea is to put trees on terraces to absorb $\mathrm{CO} 2$. Another example of this use of nature in architecture is The Canopia Apartment in Bordeaux, designed by Sou Fujimoto, is an apartment tower with several plants on its terraces.

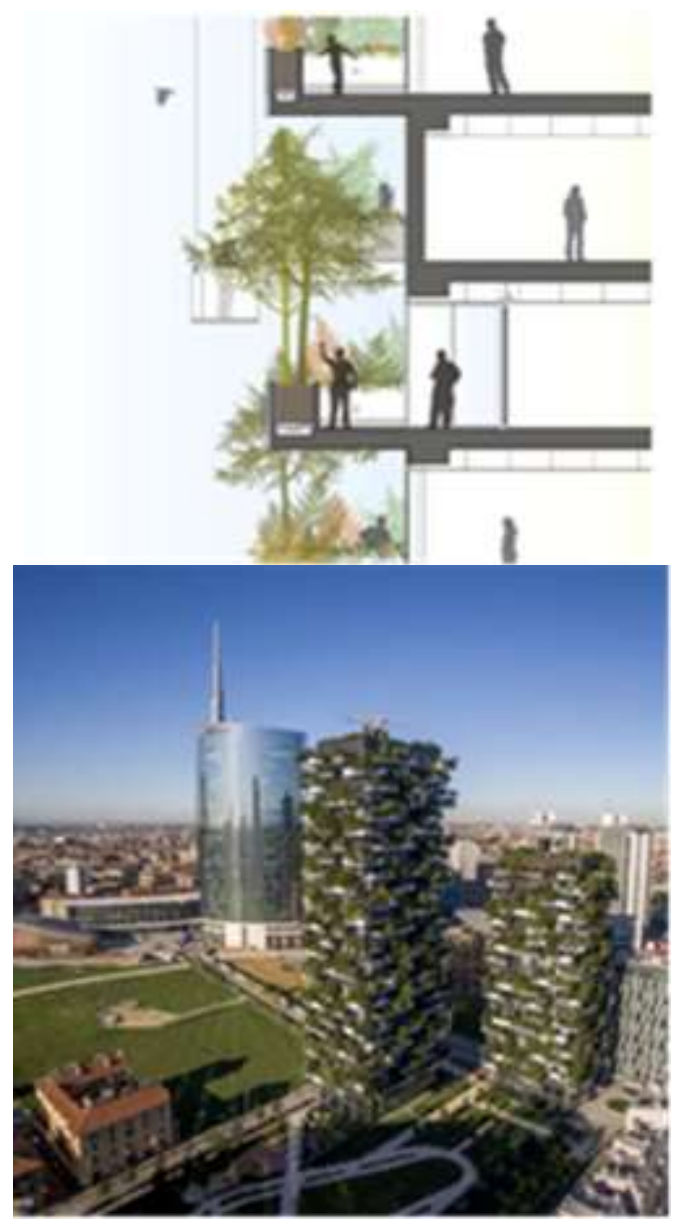

Figure 5. Bosco verticalle, by Stevano Boeri Architects, 2015
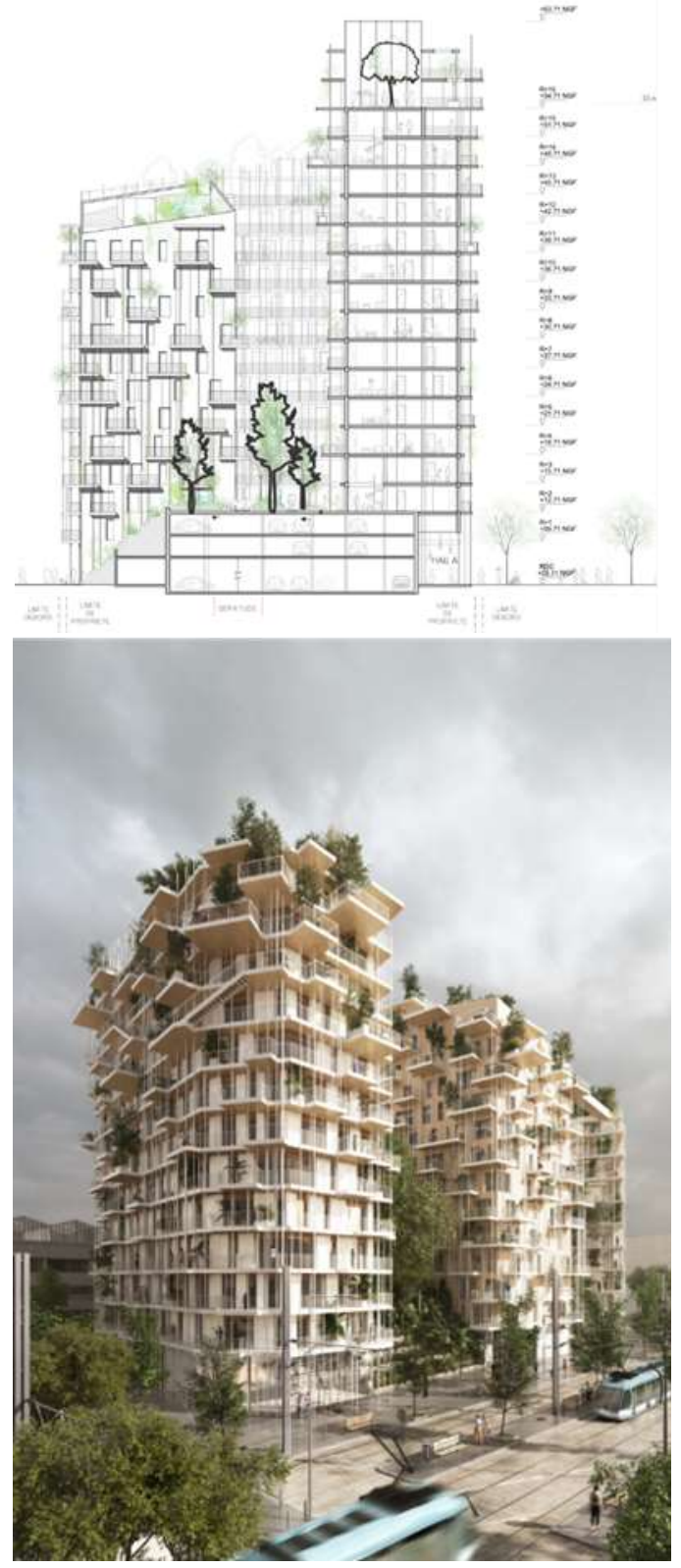

Figure 6. Canopi, by Sou Fujimoto and Laisné Roussel Propose Wooden Mixed-Use Tower for Bordeaux, 2016

Binh House, a work by Vietnamese architect Vo Trong Nghia of VTN architects, interprets the relationship between nature and architecture as a link between rooms. The living space also serves as a link among three generations of families which live in one house. 

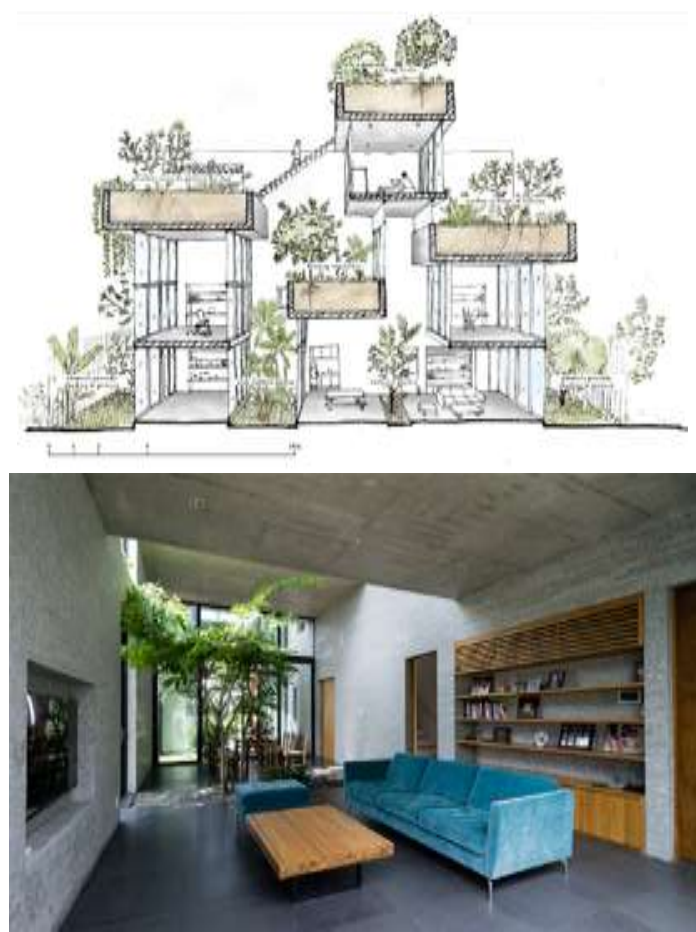

Figure 7. Binh house, by Vo Trong Nghia Architects, 2016

The next case study is the House for Trees project, where the building is used as a giant pot holding a large tree. Four masses of buildings create the pot and can be occupied by people.

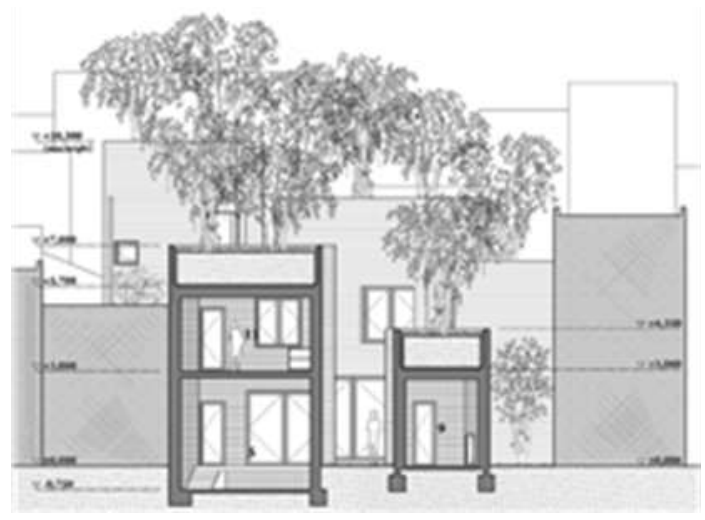

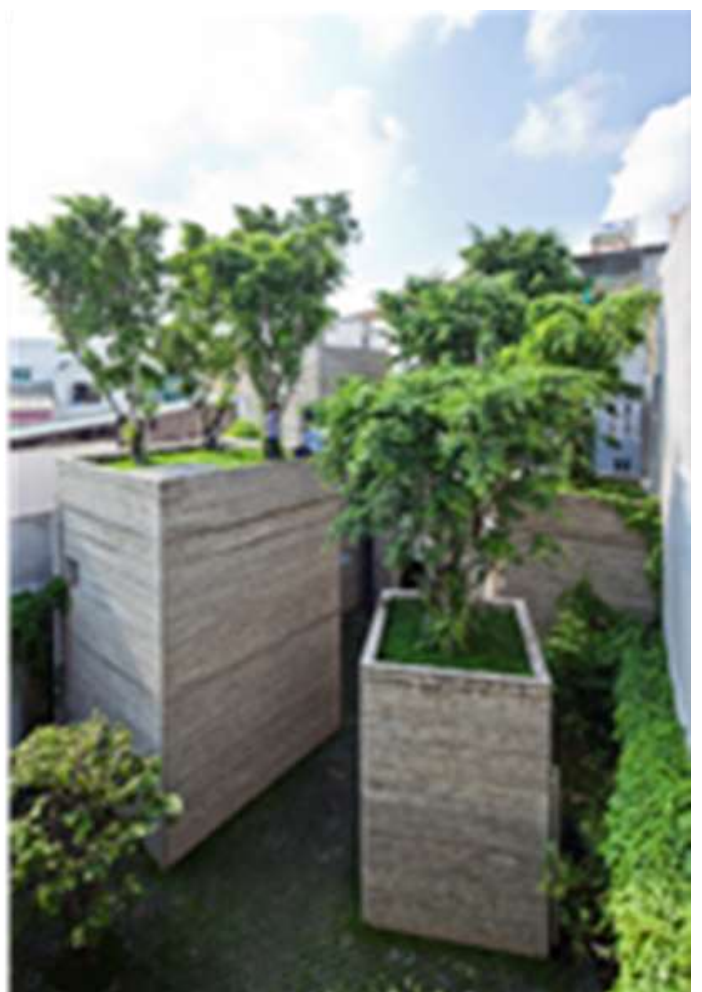

Figure 8. House for trees, by Vo Trong Nghia Architects, 2014

From the above examples, we can conclude that some new architecture in European countries attempts to get closer to nature by adding it to the outside or attaching it to the building, while some examples of new buildings in tropical countries unite architecture and nature in the interior. This proximity creates a certain quality in the space, rendering the space more interesting and enriching it with natural light and the colours of plants.

\section{Green architecture}

Toward the end of this decade, green architecture has become a hot topic for several reasons, one of them being awareness of environmental degradation. Green architecture principles serve to conserve energy by means such as reducing the use of AC. This movement is supported by the development of energyconserving technology, for example lightemitting diode (LED) lights and solar energy. The green architecture movement has resulted in the passing of various rules and systems, such the Leadership in Energy and Environmental Design (LEED) rating system in the United States, which applies to all architects. In tropical countries like 
Indonesia, green architecture is sought by the general public as well as architects.

There are several implementations involved in green architecture. One of them is a heatreduction strategy created by attaching plants to a building's façade. This makes the building look greener and changes architecture, which was removed from nature in the colonial era, to one with almost no distance from nature. Another trend can be implemented almost anywhere: many architects are experimenting with adding soil and plants on top of flat, concrete roofs. Some architectural works also plant trees inside the house. Thus, much architecture is covered with nature.

The awareness of the need for nature and its resulting green architecture movement have spread all over the world. Some experts call this the birth of an 'Environmental Age' which promotes sustainability. According to Olgyay, 'The greatest lesson is the fundamental principle that architecture is at its best when it is working with not against nature. That severance of the historical symbiosis with climate was achieved at a cost to both architecture and nature' (Olgyay, 1963, as cited in Hawkens, 2002, p. 6). We also understand that the human body acts both physically and psychologically to reach a biological equilibrium, a type of 'comfort zone'. 'A balance shelter plays a vital role in reaching this "comfort zone", which modifies the natural environment to satisfy physiological needs. In this regard the primary intention of bioclimatic building is to react to the climate and environment by absorbing, filtering or repelling environmental elements depending on their positive or negative effects on human comfort' (Olgyay 2015). Some research states that bioclimatic buildings use five to six times less energy than conventional buildings over their lifetime (Jones, 1998, as cited in Hyde, 2008) (Liébard and André 2011). Manipulating the building or microclimate may obtain thermal comfort.

\section{Use of air conditioning}

Air conditioning (AC) technology in tropical countries like Indonesia has changed the interior composition of buildings, as the use of this cooling technology is calculated based on room volume. Since smaller rooms require less AC, many house sizes are decreased to minimise $\mathrm{AC}$ use. These house sizes stand in contrast to the Dutch buildings in Menteng, which generally have high ceilings. However, in the newer residential areas of Greater Jakarta, such as Bumi Serpong Damai, Bintaro and Serpong, almost all houses have low ceilings, ranging in height from about 2.5 meters to 3 meters. The usage of $\mathrm{AC}$ has changed the relationship between architecture and nature in that the boundaries between them, which previously were ambiguous, are now defined by rigid materials. Rooms within buildings are segregated and isolated. Transparent materials such as glass and acrylic are used to maintain some contact with the exterior, but, as in the 1930 's, nature is once again relegated to a mere object of beauty.

An example of nature becoming the mere complement of architectural beauty can be found in House $\mathrm{N}$ by Sou Fujimoto, which comprises a room inside a larger room which holds large trees.

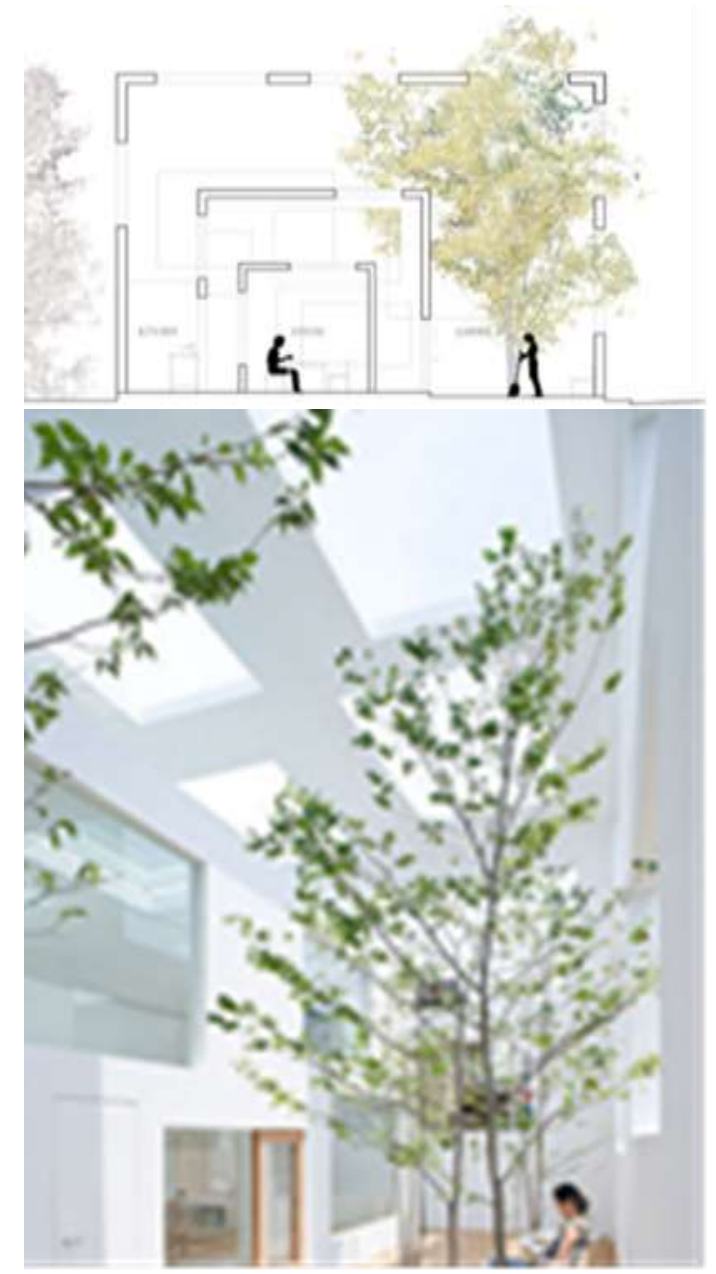

Figure 9. House N, by Sou Fujimoto Architects, 2008 


\section{Smartphone technology in the home}

Smartphone technology, which has risen in popularity since the 1990s, has changed the house floor plan typology. In the 80s, every house had a formal living room. More recently, the less formal family room has risen in demand. Today, people connect less frequently by visiting each other; instead, they are connected through social media, and there seems to be no further need for a formal living room.

Another influence of technology on middle class houses is the transformation of the bathroom. The modern bathroom has become more spacious and comfortable. It has become a new kind of private room where urbanites may spend more time on personal devices, engaging in activities such as reading the news or communicating through social media applications. Hand-in-hand with this phenomenon is the assumption that the closer people are to technology, the stronger their urge to get closer to nature will be. Hence, modern architecture attempts to bring nature indoors.

\section{Biophilic architecture}

Affection for natural systems and their incorporation into design and man-made environments is known as biophilia (Wilson, 1984; Kellert \& Wilson, 1993) (R Kellert 2005). Human dependence on nature is closely related to the human mind and body, which are associated with environmental sensors, including light, sound, wind, weather, water, plant, animal and landscape.

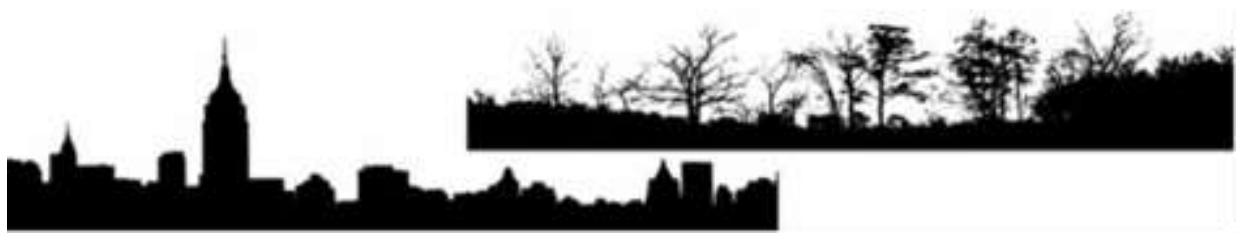

Figure 10. Interaction by face-to-face contact

Amjad Almusaed, 2011

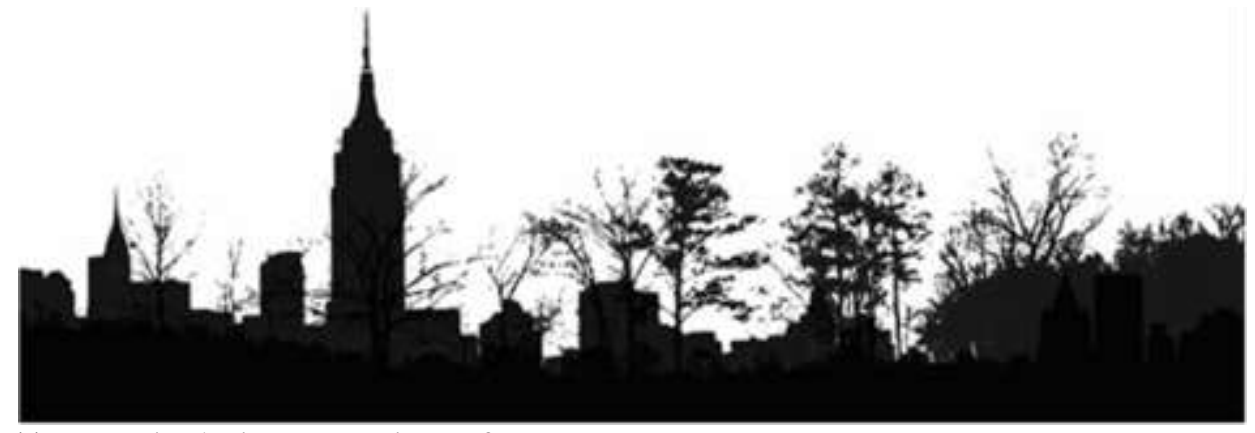

Figure 11. Interaction by interconnecting surface

Amjad Almusaed, 2011

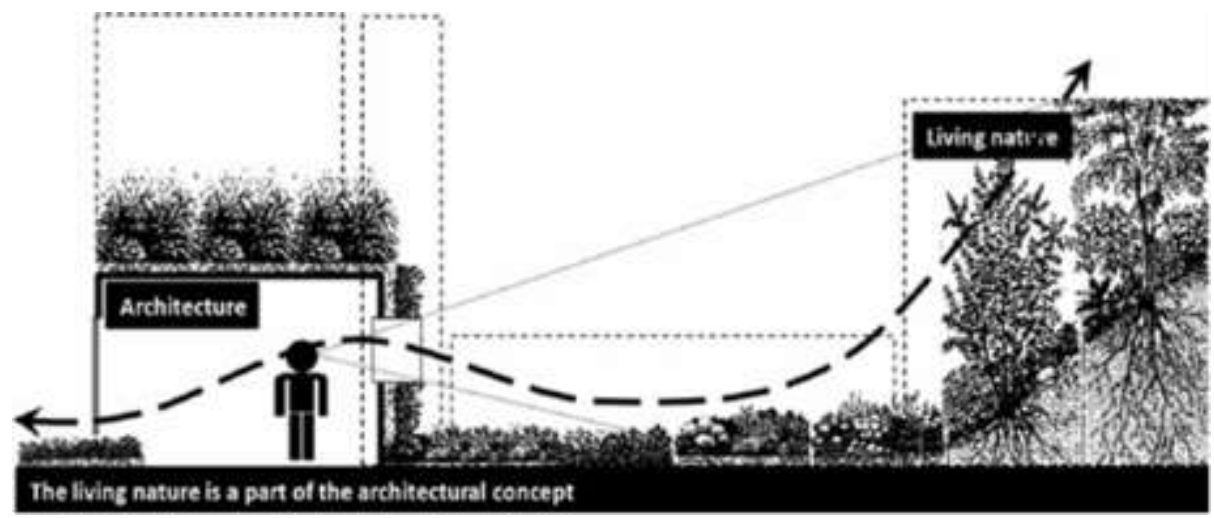

Figure 12. Architecture pattern in context of living nature upon biophilic architecture model Amjad Almusaed, 2011 
Biophilia is related to human health, productivity and wellbeing. According to Kellert (2005), the human brain responds functionally to sensory patterns from a natural environment, with many beneficial results. Kellert states that contact with nature can aid in healing or recovery from illness and that childhood health and maturity development correlate with contact with nature. Furthermore, people who live spread out in open areas are reported to have less illness and fewer social problems as compared to those who live in cities. He states that contact with nature correlates with cognitive functions which require concentration, as well as memorizing ability, pointing out that offices with natural lighting and ventilation improve employees' performance and reduce their stress. In short, a community with a positive environmental quality and a positive relationship with nature enjoys a superior quality of life (R Kellert 2005).

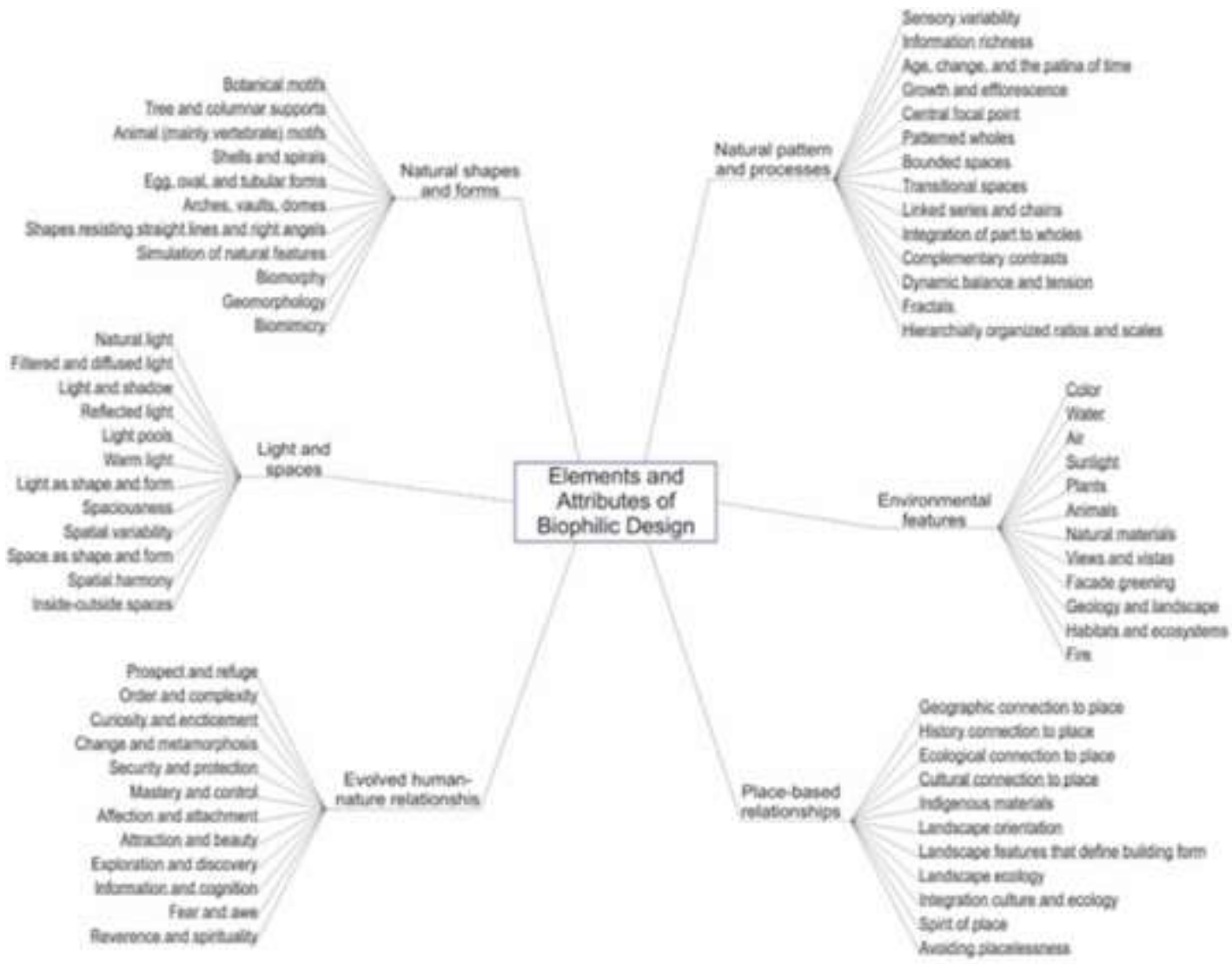

Figure 13. Elemen and attributes of biophilic design by R. Kellert, 2005

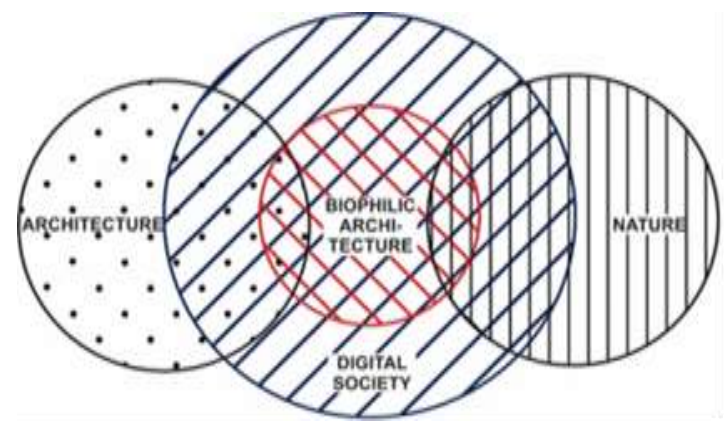

Figure 14. Relationships among digital society, architecture, nature and biophilic architecture

\section{Conclusion}

The relationship between architecture and nature can be understood as a relationship of mutual need in that human history cannot be separated from nature. From the beginning, mankind has integrated its homes with trees, especially in tropical countries, where natural resources are plentiful and well-suited to the local climate. With technological progress has come changes in architecture. Construction technology has allowed us to reduce dependence upon natural materials for building structures, using more 
sustainable materials such as concrete and steel. AC technology has also influenced new architecture, separating us from nature with the use of other materials such as glass and brick.

Segregation of nature and architecture now comes into question as humans feel a desire to return close to nature and bring nature into the building again. Contemporary architectural exploration is no longer just about how to overcome discomfort but how architects or designers may create abstract spaces in which nature and natural lighting may articulate a very specific interiority. This is in response to the transformation of modern architecture by Western influences.

With modern technology, roofs and walls may be transparent, and other creative exploration of boundaries are possible, such as contemporary louvers that can respond to heat as well as rain. This provides a new relationship between architecture and nature in which spaces are both beautiful and unique but also very easy to control in terms of temperature and lighting. Architects and interior designers face a new challenge to make use of these trends and technologies and to create a contemporary interiority by using all the human senses to understand and create contemporary abstract space.

\section{References}

Crowe, Norman. 1995. Nature and the Idea of a Man-Made World: An Investigation Into the Evolutionary Roots of Form and Order in the Built Environment. Cambridge: MIT Press.

https://mitpress.mit.edu/books/nature-andidea-man-made-world.

Liébard, Alain, and de Herde; André. 2011. "Bioclimatic Façades." https://www.somfysystems.com/file.cfm/Bi oclimatic-book.pdf?contentID=278024.

Olgyay, Victor. 2015. Design with Climate: Bioclimatic Approach to Architectural Regionalism: New and Expanded Edition. Design with Climate: Bioclimatic Approach to Architectural Regionalism: New and Expanded Edition.

Perolini, Petra. 2013. "Interior Environments : The Space of Interiority On Interiority." Zoontechnica, no. 03: 1-5. http://zoontechnica.com/occ_web/issue_03/
issue_03_essay.Interior_Environments.html \#pg_issue_03_essay.Interior_Environments .html.

Perolini, Petra Simona. 2011. "Interior Spaces and the Layers of Meaning." Design Principles and Practices: An International Journal-Annual Review 5 (6): 163-74. https://doi.org/10.18848/18331874/cgp/v05i06/38247.

Pradono, Budi. 2014. NoClay City. Jakarta: BPA publishing.

Prijotomo, Josef. 2008. Pasang Surut Arsitektur Indonesia. Surabaya: Wastu Lanas Grafika.

R Kellert, Stephen. 2005. Dimensions, Elements, and Attributes of Biophilic Design. Edited by Stephen R. Kellert; Judith H. Heerwagen; Martin L. Mador. Biophilic Design: The Theory, Science, and Practice of Bringing Buildings to Life. https://www.researchgate.net/publication/2 84608721_Dimensions_elements_and_attri butes_of_biophilic_design.

Rinaldi, Nicola. 2009. "Thermal Mass, Night Cooling and Hollow Core Ventilation System as Energy Saving Strategies in Buildings," no. April. http://kth.divaportal.org/smash/get/diva2:423877/FULLT EXT01.pdf. 
ARTEKS : Jurnal Teknik Arsitektur, Volume. 3, Nomor 2, Juni 2019 eISSN 2541-1217; pSSN 2541-0598 